Ege Tıp Dergisi / Ege Journal of Medicine XX(X):XX-XX Baskı öncesi online görünüm tarihi / Epub ahead of print: $\mathrm{XXXX}$

\title{
Hipertrigliseridemiye bağlı akut pankreatit hastalarının acil serviste yönetimi
}

\begin{tabular}{l} 
Management of hypertriglyceridemia induced acute pancreatitis in emergency department \\
IIhan Uz@ Enver Özçete Meltem Songür Kodik@ Murat Ersel@ Güçlü Selahattin Kıyan@ \\
Ege Üniversitesi Tıp Fakültesi, Acil Tıp Anabilim Dalı, Izmir, Türkiye \\
\hline \hline
\end{tabular}

Amaç: Bu yazıda, hipertrigliseridemik akut pankreatit (HTGAP) tanısı alan hastalarda acil servis yönetimi ile ilgili deneyimlerimizi paylaşmayı amaçladık.

Gereç ve Yöntem: Ekim 2015-Ekim 2016 tarihleri arasında, acil servisimize başvuran ve HTGAP tanısı alan hastaların lipaz, amilaz, trigliserid değerleri ve aldıkları tedavi rejimleri incelendi. Ortalama 1 gün/24 saat boyunca acil serviste takip edilen hastaların, klinik durumları ve başlangıç ile 24 saat sonraki trigliserid, amilaz, lipaz düzeyleri değerlendirmeye alındı.

Bulgular: Çalışma süresi boyunca acil servisimize toplam 142.482 hasta başvurdu. Bu hastalardan akut pankreatit (AP) tanısı alan hasta sayısı 370' ti. Bu hastalar içerisinde HTGAP tanılı 23-56 yaş aralığındaki 10 hastanın yaş ortalaması $36.2 \pm 19.8$ olup 6' sı kadındı. Hastaların 7' sinde hiperlipidemi, 6' sında diyabet, 2' sinde hipotroidi öyküsü vardı. Altı hasta daha önce pankreatit atağı geçirmişti. Hastaların hepsine, tanı anından itibaren acil serviste insülin infüzyon tedavisi başlandı. Ortalama 1 gün boyunca acil serviste takip edilen hastaların, klinik durumu ve 24 saat sonraki trigliserid, amilaz, lipaz düzeylerinin gerilediği görüldü.

Sonuç: Acil serviste AP' li hastalarda, etiyolojide hipertrigliseridemi akılda bulundurulmalıdır. HTGAP tanısı alan hastalarda komplikasyonları azaltmak için acil serviste erken tedavi başlanabilir ve insülin infüzyonu tedavisi, aferez tedavisine göre daha pratik ve takibi daha kolay olduğu için tüm hastalarda ilk seçenek olarak tercih edilebilir.

Anahtar Sözcükler: Acil servis, hipertrigliseridemiye bağlı akut pankreatit, insülin tedavisi.

\section{Abstract}

Aim: In this report, we aimed to share our experience on the treatment of hypertriglyceridemia induced acute pancreatitis (HTGIAP).

Materials and Methods: Between October 2015-October 2016, treatment protocols and lipase, amylase and triglyceride levels of the patients who admitted to our emergency department (ED) and diagnosed as HTGIAP were included in the study. Patients' basal and after 24 hours lipase, amylase and trigelyceride results and clinical findings were also recorded.

Results: During the study period, 142.482 patients were admitted to our emergency department. Of this overall number, 370 patients were diagnosed as acute pancreatitis $(A P)$. Among these patients, the mean age of 10 patients who were diagnosed with HTGAP was $36.2 \pm 19.8$ and six of them were female. Seven of these patients had a history of hyperlipidemia, 6 had diabetes mellitus, 2 had hypothyroidism and 6 patients had a prior acute pancreatitis attack. In ED, after the diagnosis of HTGIAP, insulin infusion treatment was started to all the patients. Average follow-up time in the ED is about one day and after 24 hours, severity of clinical signs were regressed and levels of triglyceride, amylase, and lipase were decreased in all patients.

Conclusion: Emergency physicians should kept hypertriglyceridemia in mind in differential diagnosis of acute pancreatitis. To reduce the complication rate in patients who diagnosed as HTGIAP in the ED, early treatment protocol should be applied. Insulin infusion treatment may be preferred as first choice in these cases, because it is more practical and is easier to follow than apheresis treatment in the ED conditions.

Keywords: Emergency department, hypertriglyceridemia induced acute pancreatitis, insulin therapy.

\footnotetext{
Yazışma Adresi: İlhan Uz

Ege Üniversitesi Tıp Fakültesi, Acil Tıp Anabilim Dalı, İzmir, Türkiye

Geliş Tarihi: 22.02.2018 Kabul Tarihi: 25.05.2018
} 


\section{Giriş}

Hipertrigliseridemi (HTG), serum trigliserid düzeyinin 150 mg/dL' nin üzerinde olması durumudur. Primer olabildiği gibi; kronik alkol tüketimi, diyabet, gebelik veya ilaçlar gibi sekonder nedenlere bağlı gelişebilir. Trigliserid düzeyi 1000 mg/dL' nin üstü ise ciddi HTG var demektir (1).

Ciddi trigliserid (TG) yüksekliği, non-biliyer akut pankreatit (AP) gelişiminde önemli bir risk faktörüdür. Safra kesesi taşı AP' in en sık nedeni olmakla birlikte; kronik alkol tüketimi ve HTG diğer sık nedenler arasında yer almaktadır $(2,3)$.

Literatüre göre hipertrigliseridemik akut pankreatit (HTGAP) batılı ülkelerde \%1.3-5 oranında görülmekte iken, uzak doğuda bu oran \%13-25 gibi yüksek değerlere çıkmaktadır $(1,4)$. Son yıllarda yapılan çalışmalarda da diğer etiyolojik nedenlere göre sıklığı giderek artmaktadır (5).

Pankreatite bağlı komplikasyonların engellenmesi ve pankreatitin tedavisi için trigliserid düzeyinin hızla düşürülmesi önemlidir (6). Aferez, insülin infüzyonu ve heparin, tedavi seçeneklerinde ilk sıralarda yer almasına rağmen, son yıllarda yapılan yayınlarda HTGAP tedavisinde, insülin infüzyon tedavisinin sık kullanıldığı görülmektedir.

Biz, bu yazıda, acil servisimize başvuran HTGAP tanısı alan hastalarımızın geriye dönük klinik izlemlerini paylaşmayı amaçladık.

\section{Gereç ve Yöntem}

01.10.2015-01.10.2016 tarihleri arasında acil servisimize başvuran ve HTGAP tanısı alan hastaların lipaz, amilaz, trigliserid değerleri, batın ultrasonografisi ve batın tomografisi tetkikleri incelendi.

Hastaların hepsine, tanı anından itibaren acil serviste, $0,05-0,1 / \mathrm{kg} / \mathrm{h}$ üniteden insülin infüzyon tedavisi başlandı. Kan glukoz düzeylerini 150-200 mg/dL seviyesinde tutacak şekilde dekstroz infüzyonu yapıldı. Tedavi başladığımız 2 hasta daha sonra yattığı klinikte plazmaferez tedavisi aldı. Ortalama 1 gün boyunca acil serviste takip edilen hastaların, klinik durumu ve 24 saat sonraki trigliserid, amilaz, lipaz düzeyleri değerlendirmeye alındı.

\section{Bulgular}

Çalışma süresi boyunca acil servimize toplam 142.482 hasta başvurdu. $\mathrm{Bu}$ hastalardan AP tanısı alan hasta sayısı 370' ti. Bu hastalar içerisinde HTGAP tanısı alan hasta sayısı 10' du.

Yaş aralığı 23-56 olan 10 hastanın yaş ortalaması $36.2 \pm 19.8$ idi. Dördü erkek, 6' sı kadın olan hastaların acil servis başvuru anına kadar geçen süre, yaklaşık 32 saatti. Hastaların 7' sinde hiperlipidemi, 6' sında DM, 2' sinde hipotroidi öyküsü vardı. Altı hasta daha önce pankreatit atağı geçirmişti. Üç hastanın kolesistektomi, 3 hastanın da apendektomi operasyonu öyküsü mevcuttu. HTGAP tanısı alan 10 hastanın hiç birisinde kronik veya düzenli alkol tüketim öyküsü yoktu.

Genel olarak hastaların ağrı karakterleri bulantı ve kusmanın eşlik ettiği, epigastrik bölgeden başlayıp sırta yayılan kuşak tarzında ağrılardı. Diğer sistem muayeneleri ve vital bulguları normal olarak saptandı.

Yapılan batın ultrasonografilerinde, 5 hastada grade 2-3 hepatosteatoz izlenirken hastaların hiç birisinde biliyer patoloji tespit edilmedi. Çalışmaya alınan 10 hastanın, kontrastlı çekilen batın tomografileri non-biliyer akut pankreatit olarak değerlendirildi. CT Severity Index (CTSI) (Balthazar score), tüm hastalarda $\leq 6$ idi (7). On hastanın acil serviste kalış süreleri ortalama 35.4 saat olup, hastane yatış süresi ortalamaları 11.6 gün olarak hesaplandı. Hastaların demografik verileri, Tablo-1' de sunulmuştur.

\section{Tartışma}

Akut pankreatit etiyolojisi ile ilgili literatür gözden geçirildiğinde yeme içme alışkanlığı, genetik faktörlerin ülkeden ülkeye değişmesine bağlı olarak insidans oranları da farklı toplumlarda değişkenlik göstermektedir $(4,5)$.

Safra kesesi taşlarından sonra alkol ve hipertrigliseridemi, akut pankreatit etiyolojisinde en sık görülen nedenlerdir ve son yıllarda yapılan çalışmalarda, HTGAP insidansı, batıdan doğuya doğru gittikçe (\%1.325) arttığı görülmektedir $(4,5)$. Bizim çalışmamızda bu oran \%2.7 olarak tespit edilmiştir. Bazı hastalarda daha düşük seviyelerde olsa da, yaklaşık $1000 \mathrm{mg} / \mathrm{dL}$ veya daha yüksek bir serum TG seviyesi AP riskini artırır. AP gelişme riski TG>1000 mg/dL olduğunda yaklaşık $\% 5$ ve TG>2000 mg/dL olduğunda yüzde 10-20' dir (8).

Fransa ve Almanya' da yapılan çalışmalarda, TG> 1000 $\mathrm{mg} / \mathrm{dL}$ olan 129 ve 306 sayılık hasta grupları incelendiğinde HTGAP oranları sırasıyla \%20 ve \%19 $(58 / 306)$ bulunmuştur $(9,10)$. Biz de, birçok çalışmada sınır değer olarak TG> $1000 \mathrm{mg} / \mathrm{dL}$ alınması nedeniyle, çalışmamıza bu değerin üzerinde olan hastaları dahil ettik. Şu ana kadar şiddetli HTG olan hastaların, hangisinin pankreatit olup olmayacağı konusunda net bir kanıt bildirilmemiştir. Temel patofizyolojik kavramlar, TG 'nin pankreatik lipaz tarafından hidrolize edilmesi ve inflamatuvar değişiklikler ve kılcal vasküler hasar ile aşırı serbest yağ asidi oluşumunu içerir. Ek olarak hiperviskozite ve iskemi de belirleyici rol oynayabilir (11).

HTG nedenleri, hiperlipidemilere bağlı primer olabildiği gibi diyabet, üremi, kortikosteroid fazlalığı, ekzojen östrojenler, alkol tüketimi, nonalkolik steatohepatit, nefrotik sendrom, akromegali, hipotiroidizm, tiazid diüretikler, beta adrenerjik bloker ilaçlar gibi sekonder nedenlere bağlı da gelişebilir (12). Hastalarımızın hemen hepsinde, hiperlipidemi ve diyabet öyküsü mevcuttu. Hiç birisinde düzenli alkol tüketimi yoktu. 
Tablo-1. Çalışmaya Alınan Hastaların Demografik Verileri.

\begin{tabular}{|c|c|c|c|c|c|c|c|c|c|c|}
\hline Olgular & 1 & 2 & 3 & 4 & 5 & 6 & 7 & 8 & 9 & 10 \\
\hline Yaş/Cinsiyet & $46 / E$ & $56 / E$ & $42 / E$ & $23 / K$ & $44 / K$ & $34 / K$ & $32 / K$ & $24 / K$ & $31 / \mathrm{E}$ & $30 / K$ \\
\hline \multirow{2}{*}{$\begin{array}{l}\text { Ek } \\
\text { Hastalık/Operasyon } \\
\text { başvuru anına kadar } \\
\text { geçen ağrı süresi/saat }\end{array}$} & $\begin{array}{l}\text { KKY, HT, DM, } \\
\text { HLP/A ,K }\end{array}$ & HT, DM, HTG, P & HT, DM, HPL & HTG, P/A & $\begin{array}{c}\text { HT, DM, HITTr, } \\
\text { P, HTG/K }\end{array}$ & $\mathrm{P} / \mathrm{A}, \mathrm{K}$ & HTG, HiTr & $\mathrm{DM}, \mathrm{P}$ & DM & HTG, P \\
\hline & 48 & 48 & 48 & 4 & 72 & 24 & 24 & 4 & 24 & 24 \\
\hline 25. & $\begin{array}{l}\text { Grade 2-3 } \\
\text { hepatosteatoz } \\
\text { SK yok }\end{array}$ & $\begin{array}{c}\text { Grade } 2 \\
\text { hepatosteatoz } \\
\text { SK'de taş yok }\end{array}$ & $\begin{array}{l}\text { Normal SK'de } \\
\text { taş yok }\end{array}$ & $\begin{array}{l}\text { Normal } \\
\text { SK'de taş } \\
\text { yok }\end{array}$ & $\begin{array}{c}\text { Grade 2-3 } \\
\text { hepatosteatoz } \\
\text { SK yok }\end{array}$ & $\begin{array}{l}\text { Normal } \\
\text { SK yok }\end{array}$ & $\begin{array}{c}\text { Grade } 3 \\
\text { hepatosteatoz } \\
\text { SK'de taş yok }\end{array}$ & $\begin{array}{c}\text { Grade } 3 \\
\text { hepatosteatoz } \\
\text { SK'de taş yok }\end{array}$ & $\begin{array}{l}\text { Normal } \\
\text { SK'de taş } \\
\text { yok. }\end{array}$ & $\begin{array}{l}\text { Normal } \\
\text { SK'de taş } \\
\text { yok. }\end{array}$ \\
\hline $\begin{array}{l}\text { Batın BT-Balthazar } \\
\text { skoru }\end{array}$ & AP- 1 & AP-2 & AP-3 & AP-3 & AP-1 & AP-3 & AP-1 & AP-3 & AP-3 & AP-1 \\
\hline Glukoz & 466 & 234 & 295 & 163 & 330 & 268 & 163 & 263 & 156 & 280 \\
\hline AST & 12 & 262 & $<5$ & 26 & 30 & $<5$ & 25 & 28 & 20 & 10 \\
\hline ALT & 9 & 237 & $<5$ & 29 & 28 & $<5$ & 51 & 30 & $<5$ & $<5$ \\
\hline ALP & 122 & 286 & 64 & 68 & 62 & 58 & 66 & 56 & 84 & 83 \\
\hline Total bilirübin & 0.65 & 3.34 & 0.47 & 0.38 & 0.16 & 3.31 & 0.83 & 0.70 & 0.23 & 0.25 \\
\hline Direkt bilirübin & 0.37 & 3.08 & 0.84 & * & 0.14 & 3.77 & 0.34 & 0.30 & & \\
\hline Serum albümin & 4.7 & 4.8 & 3.8 & 3.7 & 3.1 & 2.8 & 4.2 & 3.5 & 4.2 & 3.7 \\
\hline Kalsiyum & 8.4 & 10 & 8.3 & 8.2 & 9.4 & 5.6 & 8.6 & 6.6 & 7.7 & 8.2 \\
\hline Sodyum & 127 & 135 & 122 & 132 & 132 & 121 & 130 & 130 & 126 & 122 \\
\hline LDL & 14 & 97 & 123 & 28 & 95 & 16 & 19 & 11 & & \\
\hline $\begin{array}{l}\text { 1.serum amilaz } \\
\text { (28-100 U/L) }\end{array}$ & 207 & 122 & 122 & 86 & 100 & 379 & 147 & 260 & 196 & 100 \\
\hline $\begin{array}{l}\text { 1.Serum lipaz } \\
(<60 \mathrm{U} / \mathrm{L})\end{array}$ & 665 & 297 & 506 & 712 & 979 & 981 & 403 & 1036 & 208 & 236 \\
\hline $\begin{array}{l}\text { 1.serum trigliserid } \\
\text { (<150 mg/dL) }\end{array}$ & 2742 & 1074 & 6472 & 3154 & 1546 & 2280 & 1797 & 1034 & 6201 & 5412 \\
\hline $\begin{array}{l}\text { *2.serum amilaz } \\
(28-100 \mathrm{U} / \mathrm{L})\end{array}$ & 388 & 81 & 35 & * & 54 & 151 & 59 & 124 & 46 & \\
\hline $\begin{array}{l}\text { *2.Serum lipaz } \\
(<60 \mathrm{U} / \mathrm{L})\end{array}$ & 557 & 142 & 63 & 107 & 199 & 199 & 143 & 405 & 22 & \\
\hline $\begin{array}{l}\text { *2.serum trigliserid } \\
(<150 \mathrm{mg} / \mathrm{dL})\end{array}$ & 1408 & 497 & 2200 & 479 & 231 & 933 & 755 & 606 & 1509 & \\
\hline
\end{tabular}

*2. kontrol değerleri acil servis takiplerinin ortalama 24.saatinde alınmış tetkikleridir. E: Erkek, K:Kadın, KKY: Konjestif Kalp Yetmezliği, HT: Hipertansiyon, DM: Diyabetes mellitus, HLP: Hiperlipidemi, A: Apandektomi, K: Kolesistektomi, P: Pankreatit, HTG: Hipertrigliseridemi, HiTr: Hipertiroidi, SK: Safra Kesesi. Normal değerler: Total bilirübin $0.1-1 \mathrm{mg} / \mathrm{dL}$, direkt bilirübin $<0.25 \mathrm{mg} / \mathrm{dL}$, serum albümin $3.5-5.2 \mathrm{mg} / \mathrm{dL}$, kalsiyum $8.6-10.2 \mathrm{mg} / \mathrm{dL}$.

Tanı alan hastaların klinik bulguları, genellikle diğer etiyolojilere bağlı AP' li vakalardan farklı değildir. Bununla birlikte, bazı çalışmalar, HTGAP' li hastaların diğer nedenlerden dolayı, AP olan hastalara göre genellikle daha genç olabileceğini göstermektedir (13). Hastalarımızın klinik bulguları diğer pankreatit vakalarında farklı olmamakla birlikte, yaş ortalaması oldukça genç olması literatür ile uyumluydu.

Çin ve Macaristan' da yapılan çalışmalarda, HTGAP vakalarının, diğer etiyolojilere bağlı pankreatitlere göre daha yüksek mortalite ve morbidite oranları olduğu, hastanede kalış sürelerinin daha uzun olduğu belirtilmektedir $(14,15)$. Bizim hastalarımızın geriye dönük takiplerinde mortalite görülmedi.

Artan TG seviyeleri sodyum, lipaz, amilaz ve düşük yoğunluklu lipoproteinin (LDL) rutin ölçümlerini değiştirebilir. Yüksel trigliserid seviyesi, psödohiponatremi oluşturabilir (17). Hastalarımızın da hemen hepsinde hiponatremi, düşük LDL değerleri dikkatimizi çekmiştir.

Literatür incelendiğinde, afarez, insülin, heparin, oral farmakolojik ajanlar gibi çoklu tedavi yöntemleri görülmektedir (16). Pahalı ve invaziv bir yöntem olan aferez tedavisinde mekanizma, TG' nin direkt eliminasyonu, nedensel ajan çıkarılmasıdır. İnsülin mekanizması lipoprotein lipazın (LPL) aktivasyonu, şilomikron emiliminin hızlanmasına yol açar. Heparin ise, endoteliyal LPL salınımını uyarır (16).

Güncel aferez kılavuzlarında, HTGAP vakaları için aferez kullanımı endikasyon kategorisi III' tür (17). Hiçbir randomize çalışmada, HTGAP tedavisinde, aferezin, insülin ve heparin ile olan etkinliği karşılaştırılmış değildir ve şiddetli HTG' nin tedavisi için kesin bir kılavuz bulunmamaktadır. Plazmaferezin yararlı kullanımı birçok çalışmada defalarca bildirilmekte ve önerilmektedir. Bununla birlikte, randomize ve kontrollü çalışmaların bulunmaması nedeniyle, HTGAP' nin klinik ortamında plazmaferezin, morbidite ve mortaliteyi arttırıp arttırmayacağı henüz bilinmemektedir $(6,16)$.

HTG hastalarında ilk hedef, TG seviyesini kontrol ederek HTG' nin önlenmesi olmalıdır. Biz, acil serviste tanı koyulması ile beraber trigliserid düzeylerinin hızla düşürülmesi için diğer yöntemlere göre daha pratik ve daha az komplikasyonları olan insülin infüzyon tedavisinin başlanabilir olduğunu düşünmekteyiz.

Literatürde, insülin tedavisinin, özellikle hiperglisemisi olan ve/veya aferezi tolere edemeyen normoglisemik hastalar için önerilse de, bazı yayınlarda normoglisemik hastalarda da etkili olduğu yazılmıştır $(18,19)$. Çeşitli yayınlarda çeşitli dozlarda insülin infüzyonu uygulandığı görülmektedir. Jabbar ve ark. (18), normoglisemik ve hipertrigliseridemik bir hastada gemfibrozil, balık yağı ve 
insülini farklı zaman dilimlerinde trigliserid düzeylerini düşürmeyi karşılaştırmak için kullandılar ve akut dönemde insülinin, TG düzeyini hızlı düşürdüğünü bildirdiler. Subkutan tek doz insülinin (doz $0.1 \mathrm{U} / \mathrm{kg}$ ), 4 saatte TG düzeyini $1893 \mathrm{mg} / \mathrm{Dl}$ 'den $1015 \mathrm{mg} / \mathrm{dL}$ 'ye düşürdüğünü ancak, TG seviyesinin $<1000$ mg/dL'nin altında tutulmasında zorluk yaşadıklarını yazdılar. Mikhail ve ark. (19), normoglisemik bir hastada TG düzeyini $7700 \mathrm{mg} / \mathrm{dL}$ ' den $246 \mathrm{mg} / \mathrm{dL}^{\prime}$ ye düşürmek için 4 gün boyunca 3-9U/saat intravenöz insülin infüzyonu ve glikoz düzeyini 120-160 mg/dL olacak şekilde dekstroz verildiğini yayınladılar. Tamez-Perez ve ark. (20) çalışmalarında, yedi hastada, intravenöz insülin (0.05-2 U/kg/gün) kullanarak, 2,5 günde TG>1000 mg/dL'den $400 \mathrm{mg} / \mathrm{dL}$ 'nin altına düşürdüklerini bildirdiler.

Hastalarımızın kan şekerleri, $150-500 \mathrm{mg} / \mathrm{mL}$ arasında olması nedeniyle potasyum ve dekstroz replasmanı ile birlikte $0.05-0.1 \mathrm{~kg} /$ saat şeklinde başladığımız insülin infüzyonu tedavisi, acil serviste kaldığı yaklaşık 24 saat boyunca verilmiş ve kan trigliserid düzeylerinin yarı yarıya düştüğü, lipaz, amilaz değerlerinin ve klinik bulgularının gerilediği gözlenmiştir. Yattıkları kliniklerde de 10 hastanın, 8' i insülin infüzyonu ile takip edilerek, 2'si klinisyenin tercihine bağlı olarak aferez yapılarak şifa ile taburcu edilmiştir. Çalışma gurubunu oluşturan hastalarda mortalite görülmemiştir. Ancak HTGAP tanısı alan ve sadece AP tedavisi verilerek takip edilen bir karşılaştırma grubumuz mevcut değildir.

Geriye dönük olarak yazılmış ve hasta sayısının az olduğu bir çalışma olması, HTGAP tanısı alan hastalara tek tip tedavi yapılmış olması, HTG tedavisi verilmeyen hastalarla karşılaştırılmaması çalışmamızın kısıtılıklarını oluşturmaktadır. Ayrıca sadece hidrasyon ve analjezi ile takip edilen diğer pankreatit hastalarından farklı olarak hastanede kalış süreleri ve mortalite oranları kıyaslanamamıştır.

\section{Sonuç}

HTGAP, acil servislerde giderek artan oranlarda görülmektedir. Tanı konulan hastaların insülin infüzyon tedavisi acil servislerde başlanabilir. HTGAP vakalarında, TG düzeylerinin düşme süreleri, hastanede kalış süreleri ile mortalite ve morbiditelerinin insülin infüzyonu veya diğer tedavi gruplarıyla karşılaştırıldığı randomize kontrollü çalışmalara intiyaç vardır

\section{Kaynaklar}

1. Berglund L, Brunzell JD, Goldberg AC, et al. Evaluation and treatment of hypertriglyceridemia: an Endocrine Society clinical practice guideline. J Clin Endocrinol Metab 2012;97(9):2969-89.

2. Fortson MR, Freedman SN, Webster PD. Clinical assessment of hyperlipidemic pancreatitis. Am J Gastroenterol 1995;90(12):2134-9.

3. Toskes PP. Hyperlipidemic pancreatitis. Gastroenterol Clin North Am 1990;19(4):783-91.

4. Yin G, Cang X, Yu G, et al. Different clinical presentations of hyperlipidemic acute pancreatitis: A retrospective study. Pancreas 2015;44(7):1105-10

5. Zheng $\mathrm{Y}$, Zhou Z, Li H, et al. Multicenter study on etiology of acute pancreatitis in Beijing during 5 years. Pancreas 2015;44(3):409-14.

6. Tsuang W, Navaneethan U, Ruiz L, et al. Hypertriglyceridemic pancreatitis: Presentation and management. Am J Gastroenterol 2009;10(4):984-91.

7. Balthazar EJ, Robinson DL, Megibow AJ, et al. Acute pancreatitis: Value of CT in establishing prognosis. Radiology 1990;174(2):331-6.

8. Scherer J, Singh VP, Pitchumoni CS, et al. Issues in hypertriglyceridemic pancreatitis: An update. J Clin Gastroenterol 2014;48(3):195-203.

9. Lloret C, Linares AL, Pelletier S, et al. Acute pancreatitis in a cohort of 129 patients referred for severe hypertriglyceridemia. Pancreas 2008;37(1):13-20.

10. Kloer HU, Hauenschild A. Severe chylomicronemia: Clinical epidemiology and recommendations for treatment. Atheroscler Suppl 2003;4(2):234-5.

11. Valdivielso P, Ramírez-Bueno A, Ewald N, et al. Current knowledge of hypertriglyceridemic pancreatitis. Eur J Intern Med 2014;25(8):689-94.

12. Murphy MJ, Sheng X, MacDonald TM, Wei L. Hypertriglyceridemia and acute pancreatitis. JAMA Intern Med 2013;173(2):162-4.

13. Sekimoto M, Takada T, Kawarada Y, et al. JPN Guidelines for the management of acute pancreatitis: Epidemiology, etiology, natural history, and outcome predictors in acute pancreatitis. J Hepatobiliary Pancreat Surg 2006;13(1):10-24.

14. Deng LH, Xue $P, X i a ~ Q$, et al. Effect of admission hypertriglyceridemia on the episodes of severe acute pancreatitis. World $J$ Gastroenterol 2008;14(28):4558-61.

15. Baranyai T, Terzin V, Vajda Á, et al. Hypertriglyceridemia causes more severe course of acute pancreatitis. Clin Lipidol 2012;7(6):731-6.

16. Ewald N, Hardt PD, Kloer HU. Severe hypertriglyceridemia and pancreatitis: Presentation and management. Curr Opin Lipidol 2009;20(6):497-504 
17. Schwartz J, Winters JL, Padmanabhan A, et al. Guidelines on the use of therapeutic apheresis in clinical practice--evidencebased approach from the writing committee of the American Society for Apheresis: The sixth special issue. J Clin Apher 2013;28(3):145-284.

18. Jabbar MA, Zuhri-Yafi MI, Larrea J. Insulin therapy for a non-diabetic patient with severe hypertriglyceridemia. J Am Coll Nutr 1998;17(5):458-41.

19. Mikhail N, Trivedi K, Page C, et al. Treatment of severe hypertriglyceridemia in nondiabetic patients with insulin. Am J Emerg Med 2005;23(3):415-7.

20. Tamez-Perez HE, Saenz-Gallegos R, Hernandez-Rodriguez K, et al. Insulin therapy in patients with severe hypertriglyceridemia. Rev Med Inst Mex Seguro Soc 2006;44(3):235-7. 